Relations industrielles

Industrial Relations

\title{
A Very Red Life: The Story of Bill Walsh by Cy GonICK, St. John's: Canadian Committee on Labour History, 2001, 300 pp., ISBN 1-894000-05-6.
}

\section{Reg Whitaker}

Volume 57, numéro 3, été 2002

URI : https://id.erudit.org/iderudit/006897ar

DOI : https://doi.org/10.7202/006897ar

Aller au sommaire du numéro

Éditeur(s)

Département des relations industrielles de l’Université Laval

ISSN

0034-379X (imprimé)

1703-8138 (numérique)

Découvrir la revue

Citer ce compte rendu

Whitaker, R. (2002). Compte rendu de [A Very Red Life: The Story of Bill

Walsh by Cy GonICK, St. John's: Canadian Committee on Labour History, 2001,

300 pp., ISBN 1-894000-05-6.] Relations industrielles / Industrial Relations, 57(3),

589-591. https://doi.org/10.7202/006897ar

Tous droits réservés ( Département des relations industrielles de l’Universite Laval, 2002
Ce document est protégé par la loi sur le droit d'auteur. L’utilisation des services d'Érudit (y compris la reproduction) est assujettie à sa politique d'utilisation que vous pouvez consulter en ligne.

https://apropos.erudit.org/fr/usagers/politique-dutilisation/ 
employees' committees of representation, thus avoiding the issue of union recognition. The author's list and analysis of wartime orders-in-council are impressive: P.C. 3495, 2685, 2686, 5972, 7440, 4020, 4844, 7307, 10802; and finally, P.C. 1003 in February 1944, which adapted to Canada the U.S. Wagner Act on union recognition. Nine long years! And during these years, the federal government studiously skirted the issue of union recognition in important disputes such as those in National Steel Car in Ontario, and Peck Rolling Mills and Arvida in Quebec.

A third reason to remember Kirkland Lake is its subsequent political impact, particularly in Ontario. The notoriety of the Kirkland Lake strike drew the industrial unions and the CCF Party much closer than previously. The 1943 Ontario elections results showed thirty-four CCF members, nineteen of them were trade unionists. Also in 1943, the Ontario Legislature adopted a Collective Bargaining Act, modelled on the 1935 Wagner
Act of the U.S., and a forerunner of P.C. 1003 in February 1944. A few days before this latter date, Quebec had followed Ontario's lead and adopted a similar legislation. Thus, in 1943-44 and in the aftermath of the Kirkland Strike for union recognition, provincial initiatives on this issue have meant that today, ninety percent of Canadian workers are under provincial rather than federal jurisdiction.

A fourth reason to remember Kirkland Lake, as says the author, is that a strike was lost, but a battle was won. Government-enforced, employer recognition of a majority union dated 1935 in the U.S., was legislated in 1944 in Canada. Does this mean the end of the issue of union representation in its present form? Obviously not, in this reviewer's opinion. But it does strengthen the need to remember Kirkland Lake.

JEAN GÉrin-LAJOIE École des Hautes Études Commerciales Montréal

\section{A Very Red Life: The Story of Bill Walsh \\ by Cy Gonick, St. John's: Canadian Committee on Labour History, 2001, 300 pp., ISBN 1-894000-05-6.}

Bill Walsh has had a very long and colourful career as a Communist labour organizer from the 1930s to the 1960s, and subsequent to his expulsion from the party in the late 1960s, as a successful labour arbitrator. Although not as well known as some, Walsh is an important figure in both Communist and labour history. Those who have been privileged to know him over the years cherish his insights, his dedication, and above all, his endless store of anecdotes that illuminate the story of the Canadian labour left in the $20^{\text {th }}$ century. Walsh is a fit subject for a biography, and the challenge has been taken up by Cy Gonick, retired academic economist, founder of Canadian Dimension, and left activist since the 1960s.
A Very Red Life has had a lengthy and checkered career of its own. Gonick, as he notes in his introduction, is not a biographer by profession. Earlier draft versions had yet to find an authentic voice. These difficulties have been largely overcome, and the Canadian Committee on Labour History have provided an attractive format for a story that is engaging on a personal level-as biographies should be-but of wider interest as well: the life, and the times, of Bill Walsh.

Walsh was converted to Communism when he and his best friend, Dick Steele, traveling in Germany in the early 1930s, arrived almost accidentally in Russia, where they worked in Minsk and 
Moscow, before Walsh was recalled to Canada by his father, a prominent leader of the Montreal Jewish community (Walsh was born Moishe Wolofsky). He disappointed his father by plunging into Communist party organizing in the party's "golden era" of the 1930s. When the war began, Walsh was picked up and interned during the period that the Communist party was banned in Canada. Released after the Soviet Union became an ally, Walsh served with Canadian forces in Europe. During the war, his young wife died, and then Steele was killed in action. He overcame these twin tragedies, marrying Steele's widow, Esther, with whom he has remained ever since, and dedicating his abundant energies and skills to the Communist party and the class struggle in the postwar era.

The Cold War years were not friendly ground for Communist labour organizers. Walsh was dedicated, energetic, and skilled in his work, gaining over the years accumulated practical experience in what worked for the rank and file, and what did not, how to mobilize effectively, when to strike and when to settle. He worked for years on behalf of the United Electrical Workers (UE), a "Communist-led" union that survived the Cold War by providing solid service to its members. Later, cut adrift by both the UE and by the Communists, his skills found good use as an independent consultant and arbitrator.

Walsh was hardly self-effacing, but he never sought to take a leading or particularly prominent role in the party or the union. Although put forward as a Communist candidate for alderman in Hamilton, and elected in 1952 (at the height of the Red-baiting McCarthy era), he was not comfortable as a politician and soon returned to full-time labour work. Nor was he comfortable pursuing a career as a party apparatchik. Others were, and the party bosses often landed on him with orders that went against his instincts as an organizer, and with sudden changes in the party line that were the bane of the party's ordinary foot soldiers, constantly having to adjust themselves to sometimes inexplicable twists and turns. It was not easy. Indeed, the subtext of this biography, as it was of Walsh's career, was the constant tension between his dedication to the Communist ideal, and his chafing at party discipline.

Personal animosity toward him by C. S. Jackson, the abrasive Communist head of UE, ultimately led to his ejection from the union he had served so long and faithfully. The story of this breach is told here, not surprisingly, from Walsh's point of view. Readers might also consult Doug Smith's fine biography of the difficult Jackson (Cold Warrior: C. S. Jackson and the United Electrical Workers). Then in the late 1960s, Walsh was driven from the party itself. He refused to become an ex-Communist apostate, retailing horror stories about his former comrades, although there were no shortage of those. Indeed, in certain ways, Walsh has remained a believer, at least in the ideal, if not the often tawdry and sometimes nasty reality, of Communism. Gonick the biographer, never himself a CPer, has some apparent difficulty in coming to terms with Walsh's tendencies toward apologies for the Soviet Union, tendencies that long survived his expulsion from the party. The ideals of Marxism are the very essence of Bill Walsh. The USSR and the party fell short of those ideals, but to Walsh, this did not tarnish the ideals.

There is another tension touched on in these pages. Marxism was the text that informed all Walsh's actions as a labour organizer. Yet what was the purpose of labour organizing for the Communist party? Were workers to be better represented to improve their standard of living, or to recruit them to Communism? What was the relationship between labour militancy and revolution? Or, in more realistic terms, what was the relationship between labour organization 
and broader party strategy? Astonishingly, the party leadership seems never to have given any serious thought to such issues. Instead, organizers like Walsh were simply expected to fight in the trenches and be "ready, aye, ready" to do whatever they were told. Bizarrely, an equivalent mentality reigned on the other side of the Cold War barricades, where the Red-hunting RCMP Security Service watched, and fought, the Communists by fair means and foul throughout the trade union movement on the unexamined assumption that any contract gain by a 'Red-led' union automatically translated into a victory for Communism, or that the simple presence of a Communist organizer in a union somehow made that union a tool of Moscow. Bill Walsh's career offers an ironic commentary on both these Cold war orthodoxies. What remains, and is valuable, from his legacy as an organizer is what improved the bargaining power of workers, not any political gains for Communism, which were negligible in the end, in any event.
Gonick has provided a readable, sometimes entertaining, biographical portrait that fills out some corners of labour history. Inevitably, he focuses on certain parts of his subject, at the expense of others. When Walsh was being ejected from the $\mathrm{CP}$, one of his objections to the charges against him, cited here, was that the party had ignored his views on international relations, which Walsh considered important. Ironically, this is also true of Gonick. Walsh has always been a more rounded figure than perhaps emerges in this account. He is not an intellectual, never having the time nor the inclination to read widely, but as an organizer and man of action, he was always informed by a wider and more thoughtful view than the party apparatchiks who found him so troublesome. Still, his labour work has always been his real commitment, and passion. Gonick's biography has captured this very well indeed.

REg WHITAKER University of Victoria

\section{Coffret 1 : La boîte à idées : volume $M$ : Les pratiques observables du management des équipes et des personnes; volume $P$ : Le pilotage du management; Coffret 2 : La boîte à outils \\ par Jean-Louis LANGEVIN, Québec : Cap-Management, 2001, 345 p. (vol. M), 117 p. (vol. P).}

La série Cap-Management par l'auteur et consultant Jean-Louis Langevin se présente sous deux coffrets. Le premier contient un volume de base portant sur quelques concepts importants et les pratiques fondamentales qui permettent de les traduire dans le quotidien ainsi qu'un fascicule qui traite du pilotage du management, c'est-à-dire de la mise en œuvre des pratiques dans les équipes de travail et le suivi qu'il faut leur assurer. Le deuxième coffret comprend six fascicules, reprenant les six cibles de consolidation qui sont en fait un regroupement des pratiques observables. Nous donnerons ici un compte-rendu du volume de base qui demeure le plus important et le plus intéressant pour ceux qui s'intéressent avant tout aux nouveautés en gestion des entreprises et des équipes de travail.

La vision de la gestion qu'on cherche à diffuser repose sur quelques généralisations que nous formulons de la manière suivante : la performance d'une entreprise repose avant tout sur l'obtention de résultats utiles, sur des processus efficaces et sur des personnes satisfaites. Chaque ingrédient de la performance renvoie à trois valeurs fondamentales : ce qui est utile, ce qui est 